\title{
Effects of Electromagnetic Fields on the Bacterial Load of Waste Water Samples from Selected Industries in Akure Metropolis
}

\author{
Adetuyi F. C. ${ }^{1}$,Boboye B. ${ }^{1}$, Balogun O. B. ${ }^{2}$ \\ Department of Microbiology Federal University of Technology, AkureOndo State, Nigeria. \\ Department of Microbiology Joseph Ayo babalola University, Ikeji-arakejiOsun State, Nigeria.
}

\begin{abstract}
Wastewater is any water that has been adversely affected in quality by anthropogenic influence which can serve as habitat for pathogenic microbes and can constitute to health hazard of the populace. The present study was designed to enumerate and identify microorganisms in wastewaters and to investigate the effect of Electromagnetic Field (EMF) on the populations and identities of bacteria in the wastewaters from selected industries in Akure Metropolis. Wastewater samples were collected from two different industries in Akure Metropolis. The waste water samples were subjected to microbiological analyses before and after exposure to Electromagnetic field (EMF) at 1150nT, 1310nT, 3000nT, 5000nT. The presence of some bacteria in the waste water collected from different companies showed their occurrence at different hours during the treatment of the wastewater sample with different EMF strength. It was observed that at the early part (hours) of the experiment the heavy presence of microbes were seen but as the experiment progresses the microbial population were observed been reduced. It is therefore recommended that wastewater from industries should be treated with EMF before discharging them to the other water bodies so as to avoid contamination. This will help reduce microbial population that constitute a serious hazard to public health. And could also help protect other life forms inhabiting the water body and thus guard against ecological imbalance of the microbiota.
\end{abstract}

Keywords - Wastewater, Electromagnetic field, Microorganisms, bacteriological analysis.

\section{INTRODUCTION}

Wastewater: Is any water that has been adversely affected in quality by anthropogenic influence. Is one of the most critical problems of developing countries is improper management of vast amount of wastes Wastewater can originate from a combination of domestic, industrial, commercial or agricultural activities, surface runoff or storm water, and from sewer inflow or infiltration (7). Municipal wastewater (also called sewage) is usually conveyed in a combined sewer or sanitary sewer, and treated at a wastewater treatment plant. Treated wastewater is discharged into receiving water via an effluent pipe (10). Wastewaters generated from industries and there should be an on-site treatment unit. The management of wastewater belongs to the overarching term sanitation, just like the management of human excreta, solid waste and stormwater (drainage)(9).

Water of good drinking quality is of basic importance to human physiology as well as indispensable to man's continued existence. It serve as a medium of water borne disease which constitutes a significant percentage of the diseases that affect human and animals cannot be underestimated. This is the most important concern about the quality of water. Guideline for bacteriological water differs from country to country but they all conform to WHO recommendation (22). The standards for drinking water are more stringent than those for recreational waters. Investigations of how magnetic and electric fields affect living organisms at the molecular level have revealed impacts on the biological functions of organisms via changes in the concentration of hormones, activity of enzymes, transport of ions by the cell membrane or changes in the synthesis or transcription of DNA (13)

Natural water is never absolutely pure, as it carries traces of other substances which bestow on it physical, chemical and bacteriological characteristics. The nature and amount of these substances called impurities vary with sources of the water. Although, most of the water on earth is not accessible, the surface water, which is the most accessible, represents only about $0.02 \%$ of the total water resources (2). In Nigeria Akure metropolis precisely there is limited knowledge on wastewater treatment technology for small- 
scale wastewater such as cassava power plant and some water industry. Moreover, a greater population of Nigerians lack knowledge concerning the reusability potentials of treated wastewater. The waste generated from both small and large scale industry therefore does not go through any segregation and treatment Polluted water has been the cause of all such cases, in which the major sources of pollution are domestic and municipal wastes from urban and industrial activities, runoff from farmland, etc. (14). Most countries of the world now have water resources management policies aimed at achieving sustainable use Preliminary studies have suggested that the application of electric and electromagnetic fields are potentially useful methods of non thermal decontamination (9).The menace of water-borne diseases and epidemics still looms large on the horizon of developing countries as a result of lack of accessibility to good quality water (13). Chemicals that have been used to inhibit the microorganisms can cause deteriorating effects on aquatic microbiota and humans (22). Better alternative that does not have adverse effect is by the use of Electromagnetic Field.The aim of this study was to assess and to isolate and enumerate microorganisms associate with waste water, characterize microorganisms associated with wastewater from some industries in Akure. Metropolis, investigate the effects of electromagnetic field on wastewater microorganism.

\section{MATERIALS AND METHODS}

\subsection{Study Area}

Akure is situated at $7.25^{\circ}$ North latitude, 5.19 East longitude and 396 meters elevation above the sea level. Akure is a big town in Nigeria, having about 420,594 inhabitants. Owena which is located in the suburb of Owena town in Ifedore Local Government Area of Ondo-State, between latitude $7.15^{\circ} \mathrm{N}$, longitude $5.0^{\circ} \mathrm{E}$.

\subsection{Collection of wastewater samples}

Wastewater sample were collected at septic tank of different companies using sterile container and transported to the laboratory for experiment.

\subsection{Characterization and Identification of Bacterial Isolates}

The isolates were characterized using colonial and cellular morphology as well as biochemical reactions as described in Benson's microbiological application (5). They were subsequently identified using cowan and steels manual for identification of bacteria (17).

\subsection{Serial dilution}

The wastewater sample was prepared using serial dilution. $1.0 \mathrm{ml}$ of waste water sample was taken into $9 \mathrm{ml}$ sterilized distilledwater in a test tube to form a stock solution. The solution was mixed vigorously and $1 \mathrm{ml}$ was taken with the aid of sterile syringe into $9 \mathrm{ml}$ of sterilized water in another test tube under aseptic condition. These were repeated until 8 th dilution factor from which $0.5 \mathrm{ml}$ was taken into a sterile plate and then pour plate. The inoculated nutrient agar was incubated at at $37^{\circ} \mathrm{C}$ for 24 hours.

\subsection{Determination of the effects of EMF on bacterial load of waste waters.}

An electric circuit that generated the electromagnetic field wave used for this research work was designed and constructed at the Department of Physics, Federal University of Technology, Akure, Nigeria. The electromagnetic field pulse was generated from solenoid coil of hundreds of turns of copper wire. The coil was connected across a voltage source of which induced magnetic field around the coil. $1 \mathrm{ml}$ inoculums was taken and introduced into $9 \mathrm{ml}$ freshly prepared test tubes which was serially dilutedtubes. Then, the conical system were treated with electromagnetic field generated at different EMF strength respectively. Treatment of waste water with EMF: $(A=1150 n T, B=1310 n T, C=3000 n T, D=5000 n T)$ and sampling was done before exposure and at four (4) hours interval until 24 hours and 24 hours interval until 168 hours.

\section{RESULTS}

\subsection{Occurrence of the bacteria isolate}

Table 1 to 8 below shows the occurrence of the bacteria isolated from wastewater from different food companies in South West, Nigeria. The different companies where the wastewater samples were collected were named industry A and $\mathrm{B}$. In the table below, the suspected organisms, the various time in which the wastewater was exposed to different EMF strengths were shown. The time of exposure and the EMF strength affects the population of the isolates, different isolates had different reaction to these paramount and ponderous factor. The lowest EMF strength (1150nT) had the least effect on all the isolates while the highest EMF strength

Table 1 shows the effects ofemf (1150nT) on the occurrence of the bacteria on waste water from industry A from 0 hours to 144 hours i.e (7days) whichhad the lowest emf strength (nT).

Table 2 shows the effects ofemf (1310nT) on the occurrence of the bacteria in waste water from industry A from 0 hours 
to 144 hours which had higher effect on microbial load than the emf strength with (1150nT).

Table 3 shows the effects of EMF (3000nT) on the occurrence of the bacteria in waste water from industry A from 0 hours to 144 hours whichhad higher effect on microbial load than the emf strength with (1310nT).

Table 4 shows the effects of EMF (5000nT) on the occurrence of the bacteria in waste water from industry A from 0 hours to 144 hours which had higher effect on microbial load than the previous emf strength.

Table 5 shows the effects of EMF (1150nT) on the occurrence of the bacteria in waste water from industry $\mathrm{B}$ from 0 hours to 144 hours whichhad the lowest emf strength (nT).

Table 6 shows the effects of EMF (1310nT) on the occurrence of the bacteria in waste water from industry A from 0 hours to 144 hours whichhad higher effect on microbial load than the emf strength with (1150nT).

Table 7 shows the effects of EMF (3000nT) on the occurrence of the bacteria in waste water from industry A from 0 hours to 144 hours whichhad higher effect on microbial load than the emf strength with (1310nT).
Table 8 shows the effects of emf (5000nT) on the occurrence of the bacteria in waste water from industry A from 0 hours to 144 hours whichhad higher effect on microbial load than the previous EMF strength.

\subsection{Bacteria load of the wastewaters}

Figure 1 and 2 shows the microbial loads of wastewater samples from different industrial site that was subjected to different EMF strength $(\mathrm{A}=1150 \mathrm{nT}, \mathrm{B}=1310 \mathrm{nT}$, $\mathrm{C}=3000 \mathrm{nT}, \mathrm{D}=5000 \mathrm{nT}$ ) at various time. The values of the bacteria colony count was counted and recorded. Sample collected at industry A had the highest mean values with EMF strength 1150nT, after exposure to EMF at lowest hour at hours were $230 \mathrm{cfu} / \mathrm{ml}, 225 \mathrm{cfu} / \mathrm{ml}$ and $220 \mathrm{cfu} / \mathrm{ml}$ respectively, while the lowest value with EMF strength at $5000 \mathrm{nT}$ were $0 \mathrm{cfu} / \mathrm{ml}, 2 \mathrm{cfu} / \mathrm{ml}, 4 \mathrm{cfu} / \mathrm{ml}$, respectively. For sample collected at industry B had the highest values with EMF strength 1150nT, after exposure to EMF at lowest hour at 4 hours were $179 \mathrm{cfu} / \mathrm{ml}, 176 \mathrm{cfu} / \mathrm{ml}$ and $173 \mathrm{cfu} / \mathrm{ml}$ respectively, while the lowest value with EMF strength at $5000 \mathrm{nT}$ were $1 \mathrm{cfu} / \mathrm{ml}, 3 \mathrm{cfu} / \mathrm{ml}, 5 \mathrm{cfu} / \mathrm{ml}$, respectively.

TABLE 1: Microganisms isolated from industry A wastewater

ISOLATE CODE
IAI
IA2
IA3
IA4
IA5
IA6
IA7
IA8
IA9
IA10
IA11
IA12
IA13

PROBABLE MICROORGANISM

Enterobacter aerogenes

Klebsiella oxytoca

Bacillus subtilis

Proteus vulgaris

Staphylococcus aureus

Bacillus cereus

Staphylococcus saprophyticus

Lactococcus lactis

Salmonella typhi

Enterococcus faecalis

Micrococcus luteus

Pseudomonas aeruginosa

Escherichia coli 
Table.2: Effects of EMF (1510nT) on the occurrence of the bacteria on waste water from industry A.

\section{TIME (hr)}

$\begin{array}{llllllllllllll}\text { Isolate } & 0 & 4 & 8 & 12 & 16 & 20 & 24 & 48 & 72 & 96 & 120 & 144 & 168\end{array}$

code

$\begin{array}{rllllllllll}\mathrm{IA} 1 & + & + & + & + & + & + & + & - & - & - \\ \mathrm{IA} 2 & + & + & + & + & + & + & + & + & + & - \\ \mathrm{IA} 3 & + & + & + & + & + & + & + & + & - & -\end{array}$

IA $4+++$

IA $5+\quad+\quad+\quad+$

IA6 ++++

IA $7+\quad+\quad+\quad+$

IA $8+\quad+\quad+\quad+\quad+$

IA $+\quad+\quad+\quad+\quad+$

IA $10+\quad+\quad+$

$1 \mathrm{~A} 11++$

IA12 $+\quad+\quad+\quad+\quad+$

IA13 $++++\quad+\quad+$

Table.3: Effects of emf(1310nT) on the occurrence of the bacteria on waste water from industry A.

TIME (hr)

$\begin{array}{llllllllllllll}\text { Isolate } & 0 & 4 & 8 & 12 & 16 & 20 & 24 & 48 & 72 & 96 & 120 & 144 & 168\end{array}$

code

IA $1+\quad+\quad+\quad+\quad+$

IA $2+\quad+\quad+\quad+\quad+\quad+$

IA $3+\quad+\quad+\quad+\quad+\quad+\quad+$ 


$\begin{array}{llllllllllllll}\mathrm{IA} 4 & + & + & + & - & - & - & - & - & - & - & \\ \mathrm{IA} 5 & + & + & + & + & + & + & + & + & + & - \\ \mathrm{IA} 6 & + & + & + & + & + & + & + & + & + & - & \\ \mathrm{IA} 7 & + & + & + & + & + & + & + & - & + & - \\ \mathrm{IA} 8 & + & + & + & + & + & + & + & + & + & - \\ \mathrm{IA} 9 & + & + & + & + & + & + & + & + & - & - \\ \mathrm{IA} 10 & + & + & + & - & - & - & - & - & - & - \\ 1 \mathrm{~A} 11 & + & + & - & - & - & - & - & - & - & -\end{array}$

\section{Legend: (+) Present, (-) Absent}

IA1-IA13=First Isolate - Thirteen Isolate A13

Table.4: Effects of EMF (3000nT) on the occurrence of the bacteria on waste water from industry A.

\section{TIME (hr)}

$\begin{array}{llllllllllllll}\text { Isolate } & 0 & 4 & 8 & 12 & 16 & 20 & 24 & 48 & 72 & 96 & 120 & 144 & 168\end{array}$

code

IA $1+\quad+\quad+\quad+\quad+\quad+$

$\mathrm{IA} 2+\quad+\quad+\quad+\quad+\quad+\quad+\quad+\quad+$

IA $3 \quad+\quad+\quad+\quad+\quad+$

IA $4+++$

IA $5+\quad+\quad+\quad+\quad+\quad+\quad+\quad+\quad+\quad+\quad+\quad+$

IA $6+\quad+\quad+\quad+\quad+\quad+\quad+\quad+\quad+\quad+$

IA $7 \quad+\quad+\quad+\quad+\quad+$

IA $8+\quad+\quad+\quad+\quad+\quad+\quad+\quad+\quad+\quad+$

IA $9+\quad+\quad+\quad+\quad+\quad+\quad+\quad+\quad+\quad+$

$\mathrm{IA} 10+\quad+\quad+$

$1 \mathrm{~A} 11+$ 


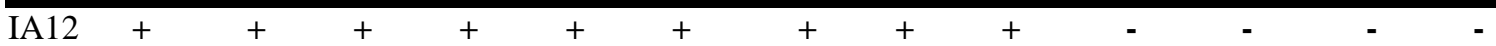

$\mathrm{IA} 13+\quad+\quad+\quad+\quad+\quad+\quad+\quad+$

\section{Legend: (+) Present, (-) Absent}

\section{IA1-IA13=First Isolate -Thirteen Isolate A1}

Table.4: Effects of EMF (5000nT) on the occurrence of the bacteria on waste water from industry A.

\section{TIME (hr)}

$\begin{array}{llllllllllllll}\text { Isolate } & 0 & 4 & 8 & 12 & 16 & 20 & 24 & 48 & 72 & 96 & 120 & 144 & 168\end{array}$

code

\begin{tabular}{|c|c|c|c|c|c|c|c|c|c|c|c|c|c|}
\hline IA1 & + & + & + & + & + & + & + & - & - & - & - & - & - \\
\hline IA2 & + & + & + & + & + & + & + & + & - & - & - & - & - \\
\hline IA 3 & + & + & + & + & + & + & - & - & - & - & - & - & - \\
\hline IA4 & + & + & + & - & - & - & - & - & - & - & - & - & - \\
\hline IA5 & + & + & + & + & + & + & + & - & - & - & - & - & - \\
\hline IA6 & + & + & + & + & + & + & + & - & - & - & - & - & - \\
\hline IA7 & + & + & + & + & + & + & + & - & - & - & - & - & - \\
\hline IA8 & + & + & + & + & + & + & + & - & - & - & - & - & - \\
\hline IA9 & + & + & + & + & + & + & + & - & - & - & - & - & - \\
\hline IA1 & + & + & + & - & - & - & - & - & - & - & - & - & - \\
\hline $1 \mathrm{~A} 11$ & + & + & - & - & - & - & - & - & - & - & - & - & - \\
\hline IA12 & + & + & + & + & + & + & + & + & - & - & - & - & - \\
\hline IA13 & + & + & + & + & + & + & + & + & - & - & - & - & - \\
\hline
\end{tabular}

Legend: (+) Present, (-) Absent

IA1-IA13=First Isolate -Thirteen Isolate A13

TABLE 6 :Microganisms isolated from industry $B$ wastewater

\begin{tabular}{cl} 
ISOLATE CODE & PROBABLE MICROORGANISM \\
\hline IAI & Micrococcus luteus \\
IA2 & Lactococcus lactis \\
IA3 & Listeria spp \\
IA4 & Escherichia coli \\
IA5 & Erwinia caratova \\
IA6 & Proteus vulgaris \\
IA7 & Staphylococcus saprophyticus \\
IA8 & Enterobacter aerogenes \\
IA9 & Bacillus subtilis \\
IA10 & Pseudomonas aeruginosa \\
IA11 & Salmonella typhi \\
\end{tabular}


Table.7: Effects Of EMF(1150nT) On The Occurrence Of The Bacteria On Waste Water From Industry B.

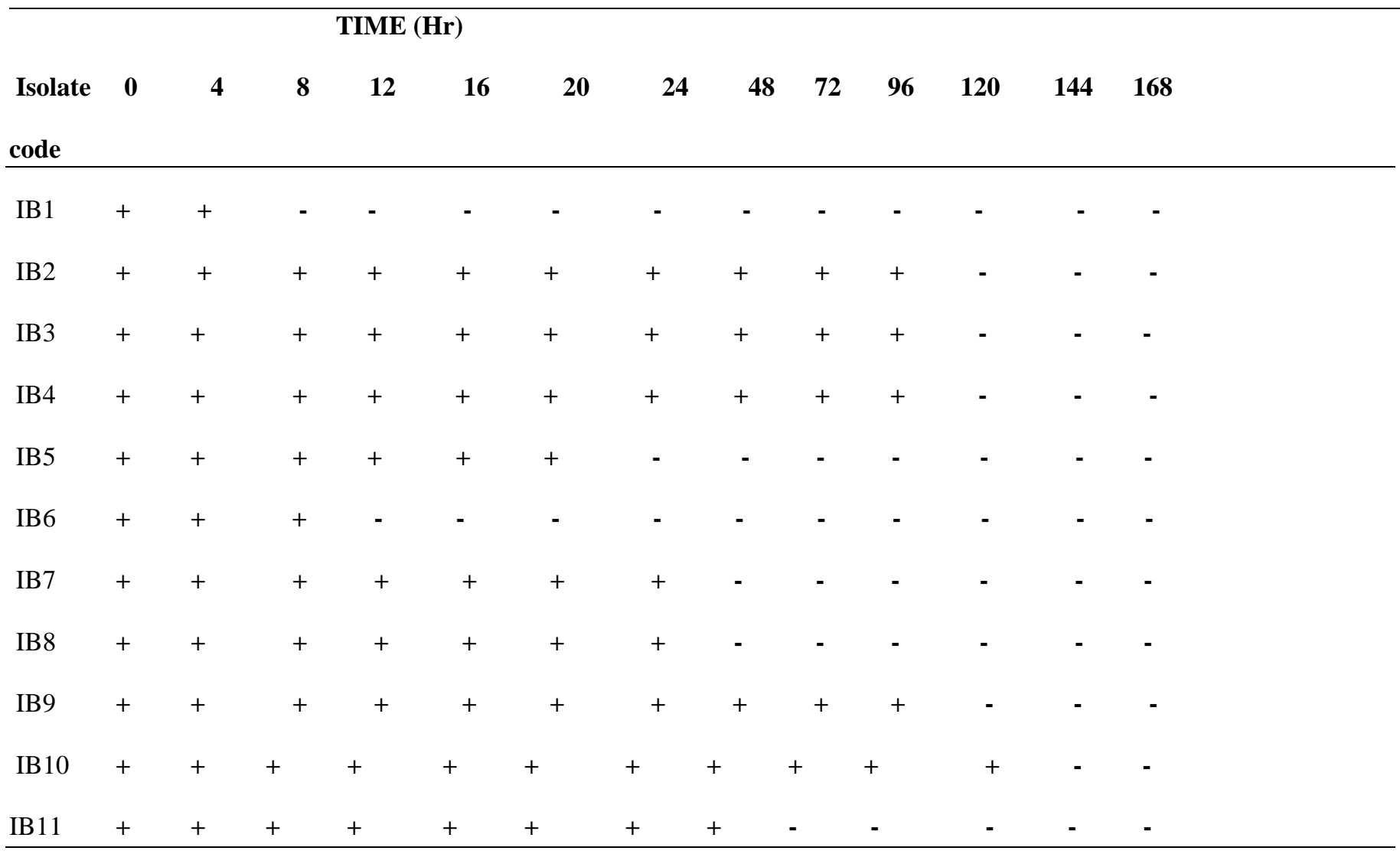

Legend: (+) Present, (-) Absent

IA1-IA13=First Isolate - Thirteen Isolate A13

Table.8:effects of EMF (1310nT) on the occurrence of the bacteria on waste water from industry B.

TIME (Hr)

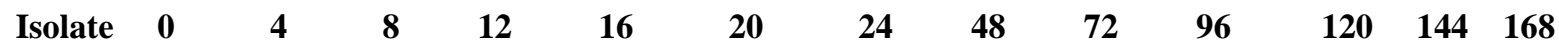

code

$\begin{array}{lllllllllll}\mathrm{IB} 1 & + & + & - & - & - & - & - & - & - & - \\ \mathrm{IB2} & + & + & + & + & + & + & + & + & + & - \\ \mathrm{IB} 3 & + & + & + & + & + & + & + & + & + & - \\ \mathrm{IB} 4 & + & + & + & + & + & + & + & + & + & +\end{array}$




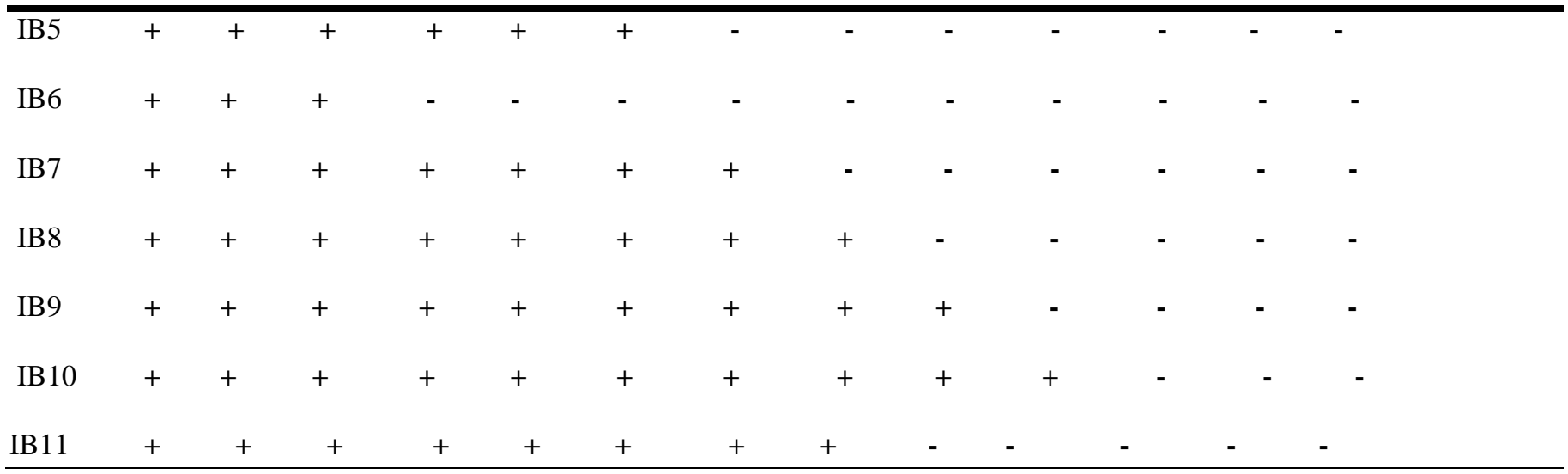

Legend: (+) Present, (-) Absent

IA1-IA13=First Isolate -Thirteen Isolate A13

Table. 9: Effects of EMF (3000nT) on the occurrence of the bacteria on waste water from industry A TIME (Hr)

$\begin{array}{llllllllllllll}\text { Isolate } & 0 & 4 & 8 & 12 & 16 & 20 & 24 & 48 & 72 & 96 & 120 & 144 & 168\end{array}$

code

\begin{tabular}{|c|c|c|c|c|c|c|c|c|c|c|c|c|c|}
\hline IB1 & + & + & - & - & - & & - & - & - & - & - & - & - \\
\hline IB2 & + & + & + & + & + & & + & + & + & - & - & - & - \\
\hline IB3 & + & + & + & + & + & & + & + & + & - & - & - & - \\
\hline IB4 & + & + & + & + & + & & + & + & + & + & - & - & - \\
\hline IB5 & + & + & + & + & + & + & - & - & - & - & - & - & - \\
\hline IB6 & + & + & + & - & - & & - & - & - & - & - & - & - \\
\hline IB7 & + & + & + & + & + & & + & + & - & - & - & - & - \\
\hline IB8 & + & + & + & + & + & & + & - & - & - & - & - & - \\
\hline IB9 & + & + & + & + & + & & + & + & + & - & - & - & - \\
\hline IB10 & + & + & + & + & + & & + & + & + & + & - & - & - \\
\hline IB 11 & + & + & + & + & + & & + & + & + & - & - & - & - \\
\hline
\end{tabular}

Legend: (+) Present, (-) Absent

IA1-IA13=First Isolate -Thirteen Isolate A13 
Table.10: Effects of EMF (5000nT) on the occurrence of the bacteria on waste water from industry B.

TIME (Hr)

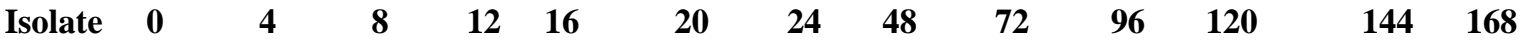

code

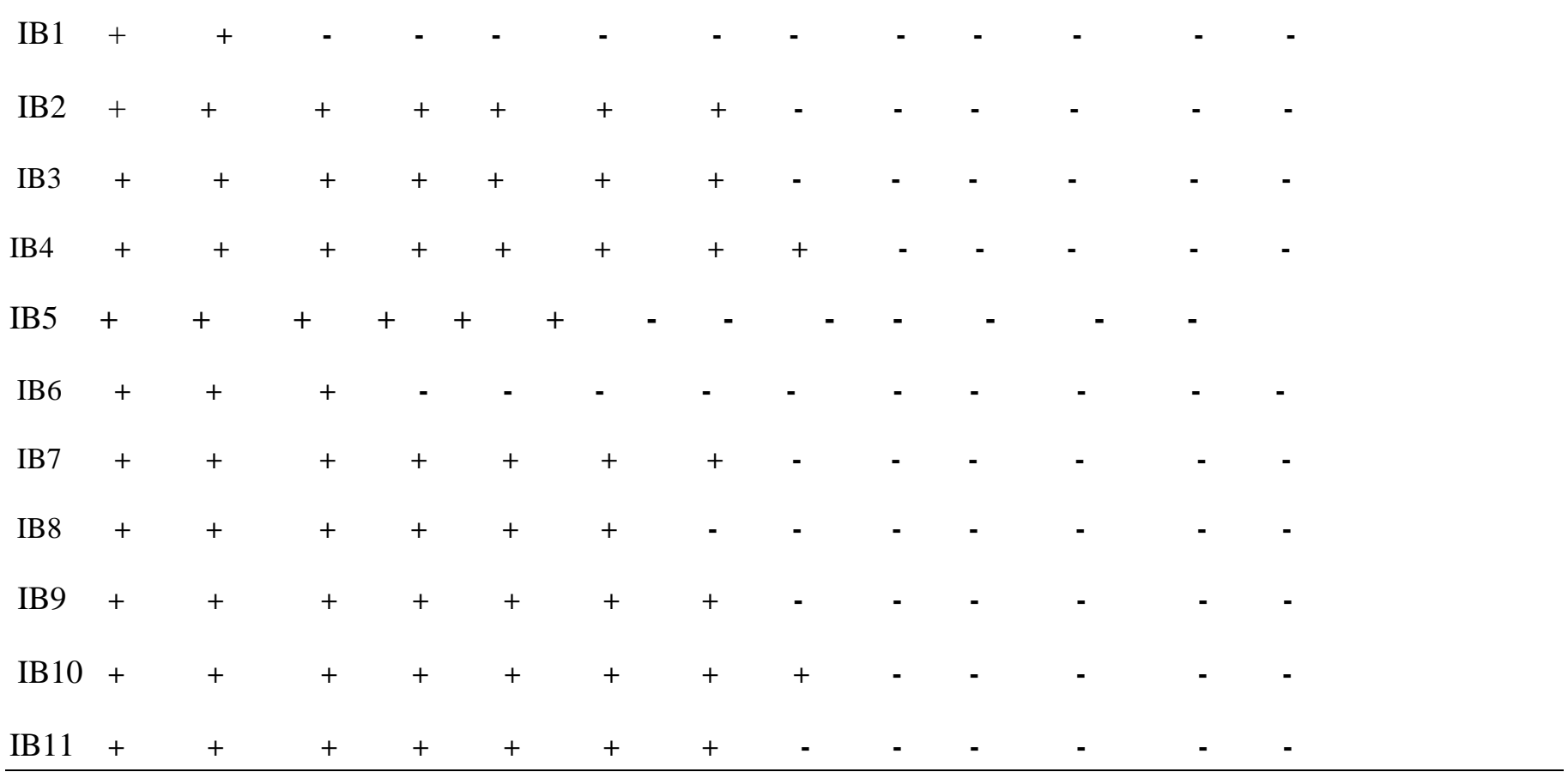

\section{Legend: (+) Present, (-) Absent}

\section{IA1-IA13=First Isolate -Thirteen Isolate A13.}

\section{DISCUSSION}

The presence of some microorganisms in the wastewater collected from different companies is demonstrating their occurrence at different hours during the treatment of the wastewater sample with different EMF strength. It was observed that at the early part (hours) of the experiment the heavy presence of microbes were seen but as the experiment progresses the microbial population were reduced.The EMF had most dwinding effect on Microcccus luteus because it was not visible after four hours of exposure for each EMF strength. Even some microbes (Bacillus subtillis, Staphylococcus aureus, Staphylococcus saprophyticus, Klebsiella oxytoca) were not visible at 96 hours of exposure for three EMF strength(1150nT, 1310nT and 3000nT) and it was not visible after seventy two hours of exposure for the last EMF strength (5000nT). (Enterococcus faecalis, Proteus vulgaris)were no longer visible after twelve hours for all EMF strength (1150nT, $1310 \mathrm{nT}, 3000 \mathrm{nT}$ and 5000nT) similar to the findings of (12). Enterobacter aerogenes after fourty eight hours for all EMF strength (1150nT, 1310nT, 3000nT and 5000nT).Bacillus cereus and Lactococcus latis was no longer visible after visible after One hundred and twenty hours of exposure, while at (1310nT and 3000nT) EMF strength it was no longer visible after ninty six hours of exposure, then at (5000nT).EMF strength it was no longer visible after twenty four hours of exposure. Salmonella typhi was no longer visible after seventy two hours of exposure for all the EMF strength (1150nT, 1310nT, 3000nT and 5000nT). (Esherichia coli and Pseudomonas 
aeruginosa) was not visible after one hundred and forty four (144) hours of exposure at $1150 \mathrm{nT}$, it was no longer visible, while at $1310 \mathrm{nT}$ it was no longer apparent after. Industry B had lesser number of microbes than industry A is consistent to the finding of (13). The EMF had most dwinding and receeding effect on Microcccus luteus because it was not visible after Eight hours of exposure for each EMF strength(1150nT, 1310nT, 3000nT and 5000nT). Esherichia coli and Pseudomonas aeruginosa was observed after 120 hours of the wastewater sample with EMF treatment and. For industry B Proteus vulgaris is no longer visible after twelve hours at all the EMF strength (1150nT, $1310 \mathrm{nT}, 3000 \mathrm{nT}$ and $5,000 \mathrm{nT}$ ) which is in contrast to what of (6) found where certain bacteria responds positively well in terms of increased growth rate and activities to electromagnetic field treatment. .Enterobacter aerogenes and Salmonella typhi is no longer visible after forty eight hours from the wastewater collected from industry B after the treatment of the wastewater sample, Lactococcus lactis, Listeria spp, Bacillus subtilis is no longer visible after one hundred and twenty hours with EMF treatment at $1150 \mathrm{nT}$, while at $1310 \mathrm{nT}$ it was not visible after exposure to ninty six hours, then after exposure to seventy two hours it was not visible at $3000 \mathrm{nT}$ and after exposure to seventy two hours it was not visible at 5000nT and other microbes were observed but in reduced population which is in contrast to what of (12) found where certain bacteria responds positively well in terms of increased growth rate and activities to electromagnetic field treatment. .Klebsiella oxytoca, Staphylococcus saprophyticus, Staphylococcus aureus was no longer visible after seventy two hours of exposure at 5000nT which also correlate to work done by (22) he allot that exposure of some bacterial cells to electromagnetic fields causes inhibition of the growth, reproduction and activities of such microorganisms. Erwinia caratova was inhibited during the course of the experiment. It was observed that the EMF treatment has a significant impact on the microbes present in the wastewater collected from different industries because it was observed that has the wastewater is been exposed to the different EMF for a longer period of time the microbial population were seen been reduced to the lowest minimum even some were not longer present in the sample before the completion of the experiment it is in agreement with the findings of (10), One of the probable explanations of the effect of electromagnetic field on the bacterial isolates might be due to the denaturing effect of EMF on the metabolites resulting from microbial activity. It could also be as a result of the rotating electric field formed by the variable magnetic field. The pulsed-electric field treatment, enhanced the bactericidal action (11), who found that electromagnetic field treatments significantly reduced the growth and proliferation of bacteria. 


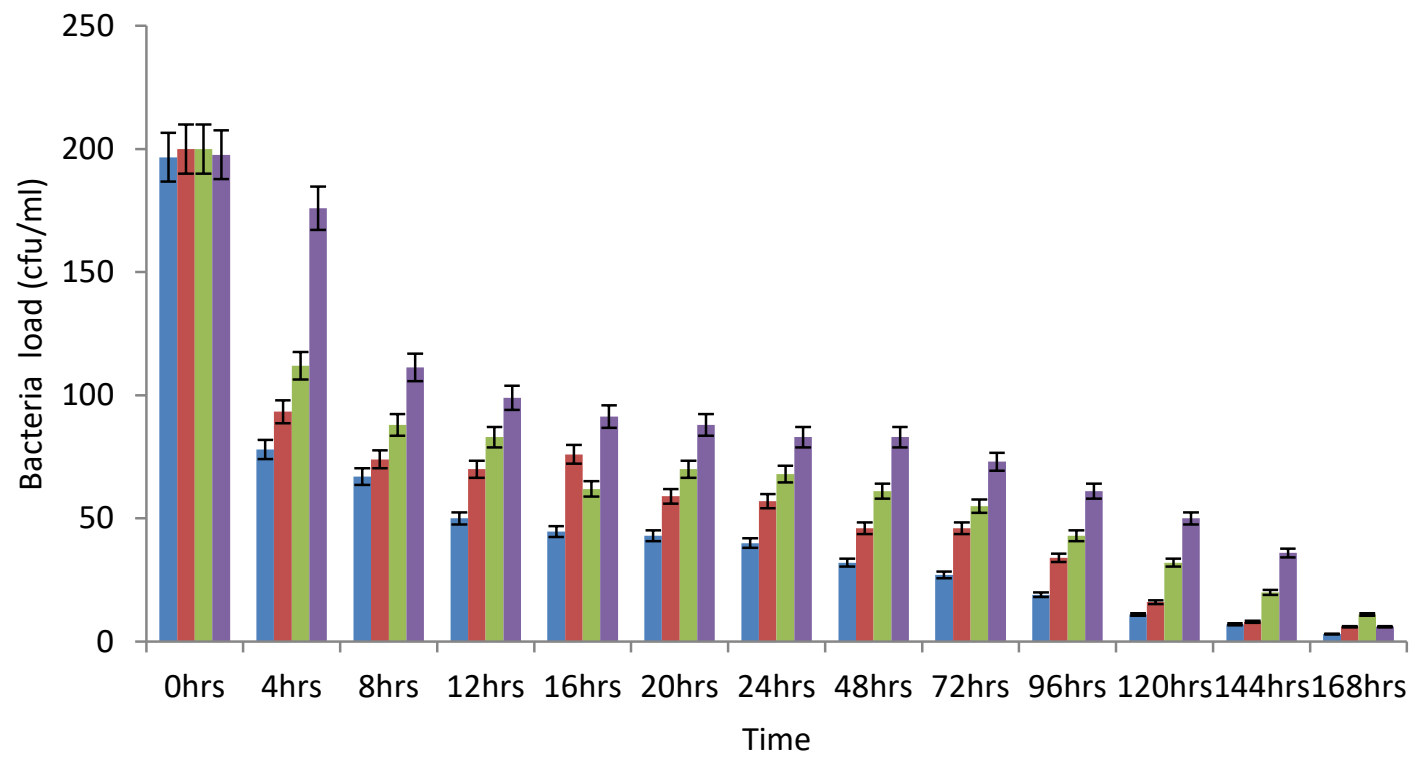

5000nT

3000nT

1300nT

1150nT

Fig.1:Effect of EMF on Bacteria Loads in Waste Water fromIndustry A

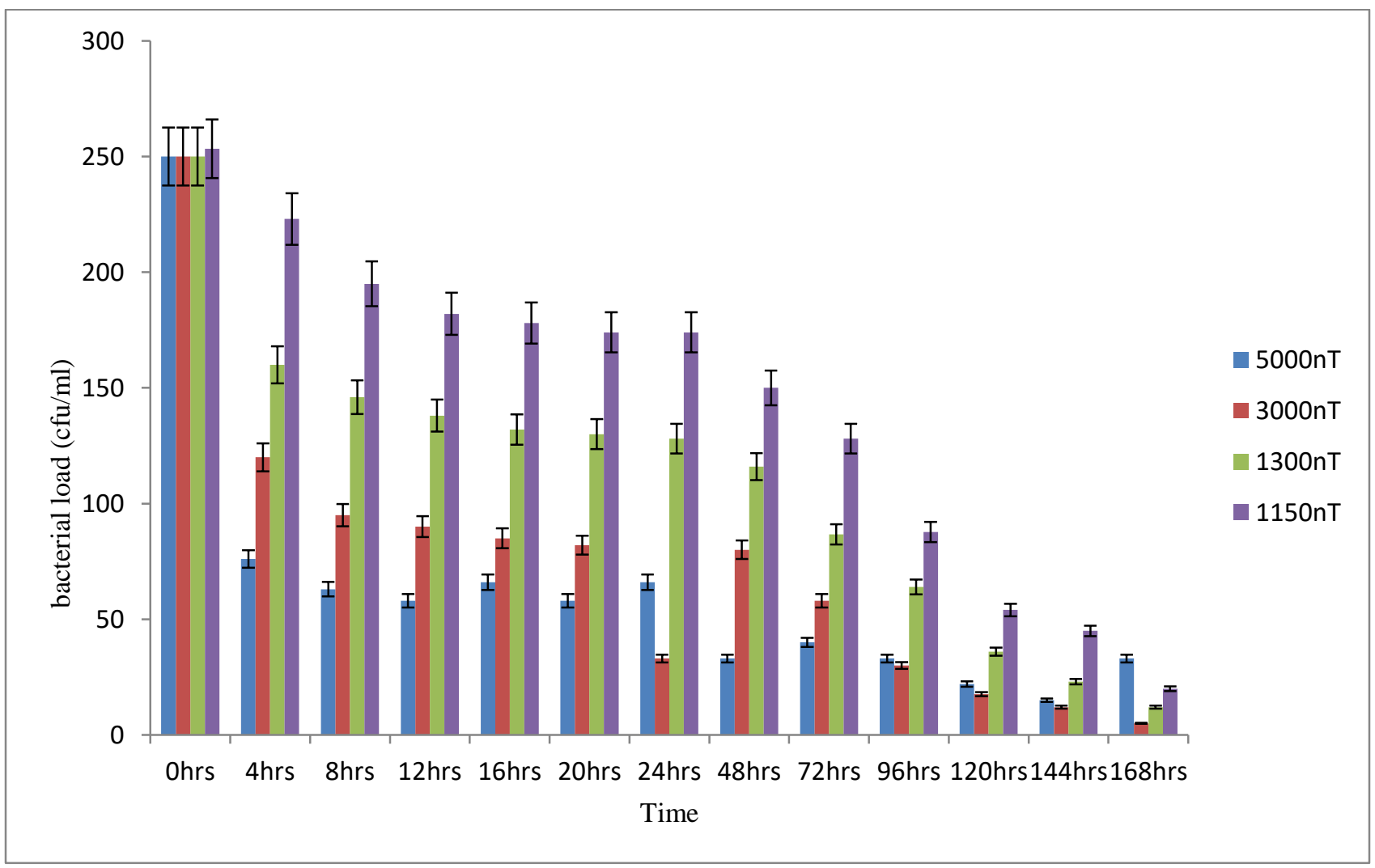

Error bars $\pm 1 \mathrm{SE}$

Fig.2: Effect of EMF on Bacteria Loads In Waste Water From Industry B. 
The results of this investigation also revealed that increased duration of exposure of bacteria to electromagnetic field resulted in the reduction in the population of the bacterial isolates as there was a considerable decrease in the colony count. The period of exposure of microbial cells to electromagnetic field plays an important role in the production of the biological effect and this can cause desirable changes in them. Human activities such as pollution also affect the activity of microbes in water and this can lead to Eutrophication, consequently have a negative effect on the relationship that exist between the microbial groups.

\section{CONCLUSION}

The EMF treatments reduced the microbial population as well as the rate of contamination in the wastewater samples as the exposure time increased and it also inhibit growth and proliferation of microorganisms thus making it to have both bacteriostatic and bacteriocidal effect.

\section{RECOMMENDATION}

It is therefore recommended that wastewater from industries should be treated with a better alternative mean by the use of electromagnetic field before discharging them to the other water bodies so as to avoid contamination. This will help reduce microbial population that constitute a serious hazard to public health. EMF treatments could also help protect other life forms inhabiting the water body and thus guard against ecological imbalance of the microbiota.

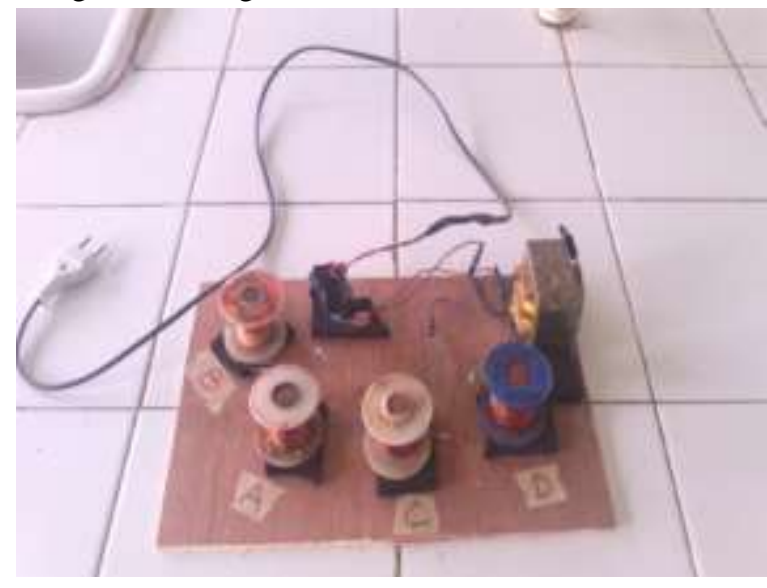

Plate 1: Electromagnetic field (EMF) apparatus set up

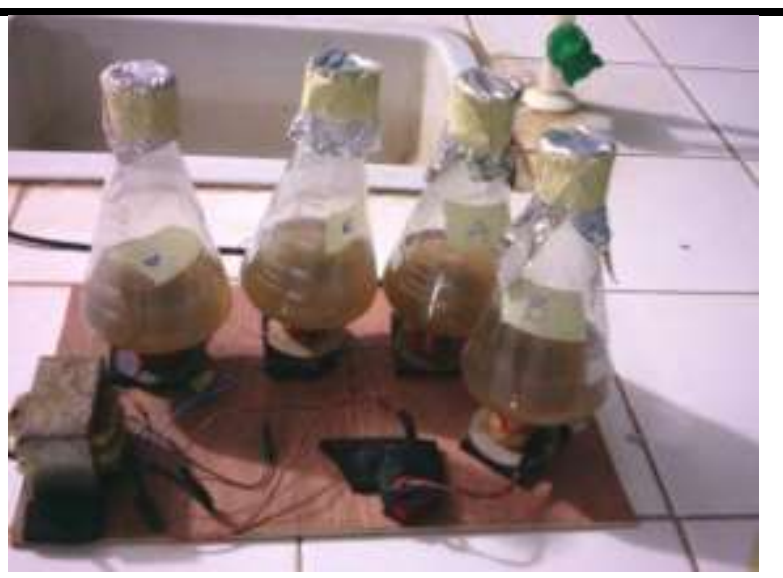

Plate 2: Setup of EMF with wastewater inside the conical flasks during the experiment

\section{COMPETING INTERESTS}

Authors have declared that no competing interests exist.

\section{REFERENCES}

[1] Aaron J., Shipman, Todd and Wilson.. Introduction to Physical Science (12 ${ }^{\text {th }}$ edition.). Cengage Learning 2014. pp. 205-206.

[2] Abdullah, MP. andKhalik, WM. A Microbial analysis of water. Malaysian Journal of Analytical Science; 2012; 16 (45). 163.

[3] APHA. Standard Methods For Examination of Water and Wastewater, $\left(20^{\text {th }}\right.$ edition), American Public Health Association, Washington D. C. 2015.

[4] ASTM International. Annual Book of ASTM Standards, Water and Environmental Technology, West Conshohocken, Pennsylvania; 2003; pp 6-7.

[5] Al-Bastaki, NM. Performance of advanced methods for treatment of wastewater: Chemical Engineering and Processing $2009 ; 43$ (7): 34

[6] Brunette S. and Gary .. (4 ${ }^{\text {th }}$ edition), CDC Health Information for International Travel. The Yellow Book, chapter 3. Oxford University Press. pp 56 Content source: Centers for Disease Control 2013.

[7] Burton, FL, and Tchobanoglous, G. and Stensel, HD. Wastewater Engineering (Treatment Disposal Reuse) / Metcalf \& Eddy, Inc. (6th edition.). McGraw-Hill Book Company 2013.

[8] Carl RN. "Electromagnet".Hyperphysics. Departmentt. of Physics and Astronomy, Georgia State University 2012.

[9] Fawole MO, Oso BA. Laboratory manual of microbiology. Ibadan, Nigeria (Spectrum Books). MD, USA. Official Method of Water Analysis. 2001;15-45. 
[10] Mizuno, A and Hori, Y. Destruction of living cells by pulsed high-voltage application. IEEE Industrial Application.1991;24(3):387-394.

[11] Moulder JE. The electric and magnetic fields research and public information dissemination. (EMF-RAPID). Programme Radiation. Research. 2002 ;153: pp 613616.

[12] Naoum, O. and Karchev, P. "Itinerant ferromagnetism and superconductivity". In Paul S. (CON) Castro. Superconductivity research at the leading edge. 2003 pp. 169.

[13] Nawlakhe, W.G.,Lutade, S.L., Patni, P.M. and Deshpande, L.S.Indian Journal of Environment. Protection;1995;37(4), pp 278-284.

[14] Oyhakilome, GI.,Aiyesanmi AF. And Akharaiyi FC. Water Quality Assessment of the Owena MultiPurpose Dam, Ondo State, Southwestern Nigeria, Journal of Environmental Protection; 2012; 3, (22):14-25.

[15] Qin, BL., Zhang, Q., Barbos, GV, Swanson, BG, Pedrow, PD). Inactivation of microorganisms by pulsed electric fields with different voltage waveforms. IEEE Trans. Dielectric. Insulations; 2014;1(6):1047-1057.

[16] Watkin, J. and Sleath KP. (1981). Journal. Applied. Bacteriology. 50: pp 1-9.

[17] Welch. Limnology ( $2^{\text {nd }}$ edition). McGraw Hill Book Co., New York 1952.

[18] WHO Geneva Guidelines for drinking-water quality (electronic resource), ( $3^{\text {rd }}$ edition) incorporating $\left(1^{\text {st }}\right.$ and $2^{\text {nd }}$ agenda), Recommendations (2008).

[19] Willey, Prescott, Harley and Klein's Microbiology, New York: The McGraw-Hill publications, 2008.

[20] Windelspecht. and Michael Ground breaking Scientific Experiments, Inventions, and Discoveries of the $19^{\text {th }}$ Century, xxii, Greenwood Publishing Group, 2003. pp 33.

[21] World Health Organisation. Chloride in Drinking Water, Background Document for Preparation of WHO Guidelines for Drinking-Water Quality, World Health Organization, Geneva, Switzerland 2003.

[22] World Health Organisation.Water and Sanitation: Protection of the Human Environment,"World Health Organisation, Geneva, Switzerland 2014.

[23] WHO. WHO Guidelines for the Safe Use of Wastewater, Excreta and GreywaterVolume IV: Excreta and greywater use in agriculture. World Health Organization (WHO), Geneva, Switzerland 2006.
[24]Zhang X., Zhang H., Zheng C., Li C., Xiong W., Extremely low frequency (ELF) pulsed-gradient magnetic fields inhibit malignant tumour growth at different biological levels Cell Biology International;2002; 26 (7) pp. 599-603. 